\title{
(2) \\ Livelihood and Revenue: Role of rattans among Mongoloid tribes and settlers of Andaman and Nicobar islands, India
}

\author{
U. Senthilkumar, R.K. Choudhary, M. Sanjappa, D. \\ Narasimhan, R. Uma Shaanker, and G. Ravikanth
}

\section{Research}

\begin{abstract}
The Andaman and Nicobar islands, located in the Andaman Sea between peninsular India and Indo-Malaya, are part of two of the 34 mega-diversity hotspots of the world. These islands are characterized by their vegetation types such as littoral, mangroves, wet and semi-evergreen forests, and rainforests, and for being the home for six aboriginal tribes of Negrito and Mongoloid descent. The islands are also home to a number of migrants and "settlers" from the Indian mainland and Myanmar. The aboriginal tribes and the settlers have a long history of association with the island's bioresources. We surveyed the ethnic uses of rattans, the unique climbing palms, about $63 \%$ of which are endemic to these islands. Our ethnobotanical survey revealed several uses of rattans by the Nicobarese and Shompens, the two major ethnic communities of the Nicobar Islands. We also estimated the revenue generated among those involved in the rattan trade (collectors, processors, and exporters).
\end{abstract}

\section{Introduction}

The Andaman and Nicobar Islands (A \& N Islands) lying between Indian sub-continent and Malaysian-Indonesian region are part of two of the 34 mega-biodiversity hotspots of the world ( $\mathrm{Cl}$ 2013). The archipelago is comprised of 348 islands and is known for its lush green rainforests, mangroves, and littoral forests (Saldanha 1987). The vegetation of the archipelago is dominated by angiosperms with ca. 2395 species of which nearly 10\% (239 spp.) are endemic (Alfred et al. 2002, Padalia et al. 2004). Populations of a number of species have dwindled due to indiscriminate exploitation of the forest resources. It is estimated that more than $60 \%$ of the species of the $A \& N$ islands are endangered (Padalia et al. 2004, Saldanha 1987).
The A \& N islands are home to six aboriginal tribes. Great Andamanese, Jarawa, Onge, and Sentinelese are of Negrito origin, whose settlements are restricted to the Andaman group of islands viz. Strait Island (Awasthi 1991), Jarawa reserve forest, Little Andaman, and Sentinel Island (Bhargava 1983, Dagar \& Dagar 1991). Negritos have a dark complexion and are short in stature with peppercorn hair. Nicobarese and Shompens are of Mongoloid origin and reside in the Nicobar group of islands viz. Car Nicobar, Chowra, Nancowry, Trinket, Katchal, Kamorta, and Great Nicobar islands (Sharief \& Rao 2007). The islands are also inhabited by settlers who are either ex-convicts from the cellular jail, migrants from the mainland, or refugees from Bangladesh, Myanmar, and Sri

\section{Correspondence}

G. Ravikanth, U. Senthilkumar \& R. Uma Shaanker, Ashoka Trust for Research in Ecology and the Environment, Royal Enclave, Srirampura, Jakkur PO, Bangalore-560 064, INDIA. gravikanth@gmail.com

D. Narasimhan \& U. Senthilkumar, Centre for Floristic Research, Department of Plant Biology and Plant Biotechnology, Madras Christian College, East Tambaram, Chennai-600 059, INDIA.

M. Sanjappa, \& U. Senthilkumar, Botanical Survey of India CGO Complex, Salt Lake City, Kolkata-700 064, INDIA.

M. Sanjappa, Department of Botany, University of Agricultural Sciences, GKVK, Bangalore-560 065, INDIA.

Uma Shaanker, School of Ecology and Conservation, University of Agricultural Sciences, GKVK, Bangalore-560 065, INDIA, and Department of Crop Physiology, University of Agricultural Sciences, GKVK, Bangalore-560 065, INDIA.

R.K. Choudhary, Agharkar Research Institute, Botany Group, G.G. Agarkar Road, Pune-411004, INDIA

Ethnobotany Research \& Applications 12:141-154 (2014)

Published: 21 March 2014 
Lanka. They have settled in most of the islands as insular groups based on their language, occupation, region, and religion. The ethnic communities and the settlers heavily depend on the natural resources for their subsistence as well as for cash income (Chauhan et al. 2004) similar to other communities of mainland (Singh et al. 2004, Uma Shaanker et al. 2004) or in other Southeast Asian countries (Peters et al. 2007).

Rattans (commonly known as "canes") are the climbing palms of the subfamily Calamoideae, family Arecaceae, distributed in wet tropical regions of the world. They comprise about 22 genera and 650 species (Dransfield et al. 2008). Among them, 556 species from 12 genera are considered as true rattans because they yield commercial canes (Dransfield et al. 2008). Found in paleotropical Africa to East and Southeast Asia in India, rattans occur in all four biodiversity hotspots-i.e., Himalaya (Basu 1992), Indo-Burma (Henderson \& Henderson 2007), Western Ghats and Sri Lanka (Ravikanth et al. 2001, 2002), and Sundaland (Nicobar islands) (Renuka et al. 2010)—and are represented by 4 genera viz., Calamus, Daemonorops, Korthalsia, and Plectocomia, with over 60 species. Among them, 19 species of Calamus, Daemonorops, and Korthalsia are found in the Andaman and Nicobar archipelago (Renuka et al. 2010).

This study was undertaken to document the ethnobotanical use and trade of rattans by Mongoloid tribes of the Nicobar Islands and by the settlers of Andaman islands respectively.

\section{Methods}

\section{Study areas}

Andaman and Nicobar archipelago in South and Southeast Asia runs in a more or less north-south direction lying between $06^{\circ} 45^{\prime}-13^{\circ} 45^{\prime} \mathrm{N}$ and $92^{\circ} 10^{\prime}-94^{\circ} 15^{\prime} \mathrm{E}$. Geographically, it is spindled from the northern Arakan Yoma hill range of Myanmar to west of the Sumatran hill range of Indonesia. The biogeographic affinities are unique, the Andaman group of islands having closer affinity with IndoMyanmarese-Thailand elements while the Nicobar group of islands share affinities with Malaysia-Indonesian vegetation (Balakrishnan \& Ellis 1996). Andaman and Nicobar Islands cover an area of $7,171 \mathrm{~km}^{2}$, which are characterized by tropical rainforests, wet and semi-evergreen forests, wet deciduous forests, mixed forests, littoral forests, and mangroves (Alfred et al. 2002, Balakrishnan 1989, Champion \& Seth 1968). These islands harbor a number of perennial streams which contain riparian flora such as species of Pandanus, Nypa fruticans Wurmb, and other mangroves. This archipelago harbors endemic flora such as gurjan (Dipterocarpus gracilis Blume), padauk (Pterocarpus dalbergioides Roxb.), marble wood (Diospyros marmorata R.Parker), and rudraksha (Elaeocarpus angustifolius Blume) (Balakrishnan 1989), and fauna with endemic species of edible-nest swiftlet (Aerodramus fuciphagus Thunb. 1812), Andaman wood pigeon (Columba palumboides Hume. 1873), Nicobar pigeon (Caloenas nicobarica L. 1758), and Andaman serpent eagle (Spilornis elgini Blyth 1863) (Alfred \& Chakraborty 2002).

\section{Data collection}

Ethnobotanical surveys were carried out in Little Andaman, Kamorta, and Campbell bay of the Nicobar islands and Baratang Island, Wumberleygunj, and Shoal bay of the South Andaman islands (Figure 1). A trade study was carried out in major export markets of rattans in Nimbudera, Billiground, Rangat, Kadamthala, Ferrargunj, Mathura, and Garamcharma of Middle and South Andaman (Figure 1). A datasheet was prepared with an aim to explore the indigenous knowledge about rattans and trade information from settlers and traders. Hindi is an administrative language as well as the primary language of this union territory. However other languages, such as Tamil, Telugu, Bangla, and Malayalam, are also spoken by various communities. Hindi, Tamil, and Malayalam were used for communication with the local people and forest guards. Forest guards helped as interpreters to communicate with the Nicobarese and Shompens communities. Informants were made aware of the scope of the research, and interviews were carried out following the International Society of Ethnobiology Code of Ethics (ISE 2006). Primary information was procured from the ethnic groups, settlers, cane harvesters, cane processors, and traders using the pre-set datasheets. The datasheet was designed as a questionnaire to explore the knowledge of utilization of rattan resources from ethnic communities and settlers. Quantitative methods were aimed at documenting the economic revenue generated by the rattan trade in the island.

\section{Rattan resources of $A \& N$ islands}

Nineteen species of rattans occur in the A \& N islands of which 12 are endemic to this region (Renuka et al. 2010). Thirteen species occur in the Andaman islands and six species occur in the Nicobar group of islands (Table 1). The plants were identified based on Basu (1992) \& Renuka (1995), and taxonomy was updated thereafter using The Plant List (2014) and Tropicos.org (2014). Voucher specimens for all except three species were deposited at Botanical Survey of India, Southern Circle, Coimbatore, and Botanical Garden Herbarium, University of Agricultural Sciences, GKVK, Bangalore, and the additional accessions for all species are available at School of Ecology and Conservation, UAS, Bangalore (Table 1).

The altitudinal preference of rattans varies from coast to 700 m (in Saddle Peak). Calamus palustris Griff., Calamus unifarius var. pentong Becc., and Korthalsia rogersii Becc. are found above $300 \mathrm{~m}$ and reach up to $700 \mathrm{~m}$. Calamus viminalis Willd. is more common in the lowland 

Mongoloid tribes and settlers of Andaman and Nicobar islands, India

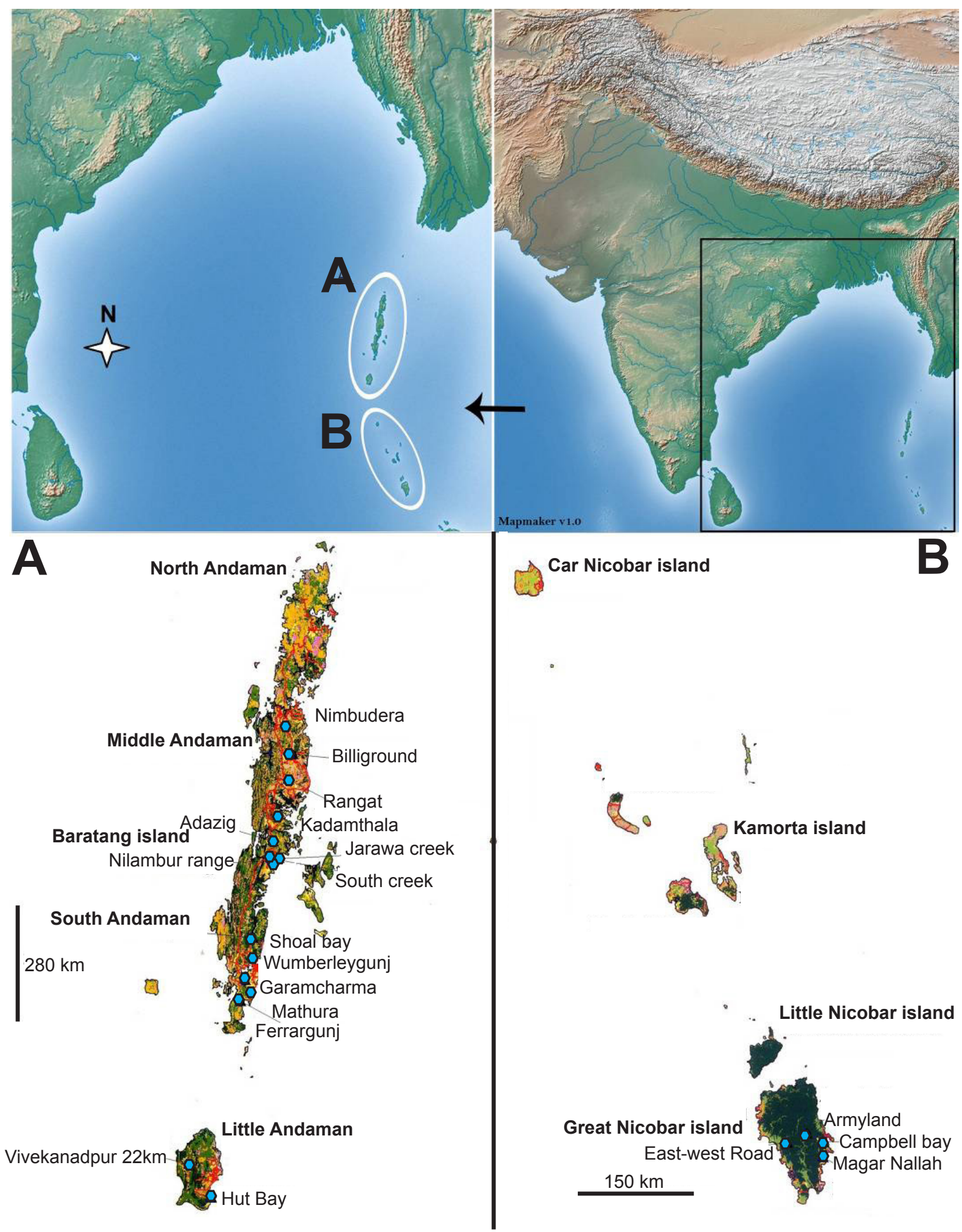

Figure 1. Andaman and Nicobar islands, India. (A) Andaman islands group, (B) Nicobar islands group. Blue hexagons indicate sites where ethnobotanical surveys were carried out. Map produced by Mapmaker version 1.0. 
Table 1. Distribution of rattans and the collection details in the Andaman and Nicobar islands, India. ( $\ddagger)$ Abundant, $(\sqrt{ })$ Less common, $\left(\sqrt{ }^{*}\right)$ Endemic to Car Nicobar, (-) Absent, $( \pm)$ Very rare/ Uncertain, (SA) South Andaman, (MA) Middle Andaman, (NA) North Andaman.

\begin{tabular}{|c|c|c|c|c|c|}
\hline \multirow[t]{2}{*}{ Species } & \multicolumn{3}{|c|}{ Andaman islands } & \multirow{2}{*}{$\begin{array}{l}\text { Nicobar } \\
\text { islands }\end{array}$} & \multirow[t]{2}{*}{ Vouchers } \\
\hline & SA & MA & NA & & \\
\hline Calamus andamanicus Kurz & $\ddagger$ & $\ddagger$ & $\ddagger$ & - & SK 692 (Mannarghat, SA) \\
\hline Calamus baratangensis Renuka \& Vijayak. & $\ddagger$ & $\ddagger$ & $\sqrt{ }$ & - & SK 686 (Chidiyatapu, SA) \\
\hline Calamus basui Renuka \& Vijayak. & $\ddagger$ & - & - & - & SK 869 (Hut bay, Little Andaman) \\
\hline Calamus dilaceratus Becc. & - & - & - & $\ddagger$ & SK 751 (Campbell Bay, Nicobar) \\
\hline Calamus longisetus Griff. & $\ddagger$ & $\sqrt{ }$ & $\ddagger$ & - & SK 818 (Lamia Bay, NA) \\
\hline Calamus nicobaricus Becc. & - & - & - & \pm & Not seen \\
\hline Calamus palustris Griff. & $\ddagger$ & $\sqrt{ }$ & $\sqrt{ }$ & - & SK 704 (Nayasahar, SA) \\
\hline Calamus pseudorivalis Becc. & - & - & - & $\ddagger$ & SK 774 (Magarnallah, Nicobar) \\
\hline Calamus semierectus Renuka \& Vijayak. & - & - & - & $\sqrt{ }{ }^{*}$ & Not seen \\
\hline Calamus unifarius var. pentong Becc. & - & - & - & $\sqrt{ }$ & SK 787 (N-S road, Nicobar) \\
\hline Calamus viminalis Willd. & $\ddagger$ & $\ddagger$ & $\ddagger$ & - & SK 699 (Wumberleygunj, SA) \\
\hline Daemonorops aurea Renuka \& Vijayak. & $\sqrt{ }$ & - & - & - & SK 749 (Shoal bay, SA) \\
\hline Daemonorops kurziana Hook.f. ex Becc. & $\sqrt{ }$ & - & - & - & SK 702 (Nayasahar, SA) \\
\hline Daemonorops manii Becc. & $\ddagger$ & $\ddagger$ & $\ddagger$ & - & SK 800 (Tharmughali Island, SA) \\
\hline Daemonorops rarispinosa Renuka \& Vijayak. & $\ddagger$ & - & - & - & $\begin{array}{l}\text { SK } 855 \text { (Krishnanallah, } \\
\text { Little Andaman) }\end{array}$ \\
\hline $\begin{array}{l}\text { Daemonorops wrightmyoensis } \\
\text { Renuka \& Vijayak. }\end{array}$ & $\sqrt{ }$ & - & - & - & SK 719 (Wrightmyo, SA) \\
\hline Korthalsia echinometra Becc. & - & - & - & \pm & Not seen \\
\hline Korthalsia laciniosa (Griff.) Mart. & $\ddagger$ & $\sqrt{ }$ & $\sqrt{ }$ & - & SK 830 (Saddle Peak, NA) \\
\hline Korthalsia rogersii Becc. & $\sqrt{ }$ & $\ddagger$ & $\sqrt{ }$ & - & SK 839 (Baratang Island, SA) \\
\hline
\end{tabular}

forests as well as in littoral forests, forest corridors, fences, and agricultural fields and coexist with species of Daemonorops, Nypa, and Phoenix. Calamus andamanicus Kurz and Korthalsia laciniosa (Griff.) Mart. are widely distributed throughout the Andaman islands where as Calamus semierectus Renuka \& Vijayak. is found only in Car Nicobar. The existence of Calamus nicobaricus Becc. in Great Nicobar is uncertain since it has not been relocated in recent decades. Daemonorops species occur only in Andaman islands and extend up to Little Andaman. They flourish on the banks of rivers, streams, dams, tidal forests, and estuaries with their robust clumps.

\section{Aborigines of the $A \& N$ islands}

Among the Asian islands, the $\mathrm{A} \& \mathrm{~N}$ islands are well known for their indigenous ethnic communities. The islands are also popularly known as "the land of the naked people" or "paradise of the pirates." The Negrito tribe inhabit the Andaman islands while the Mongoloid tribes live in the Nicobar islands. All of the tribes together account for only $9 \%$ of the total population of A \& N archipelago (Anonymous 2011). Among them, $98 \%$ are Nicobarese, who inhabit Nicobar group of islands such as Car Nicobar, Trinkat,
Kamorta, Katchal, Great Nicobar (Dagar \& Dagar 1991), and Herminder bay of Little Andaman (Sharief 2007). The other tribes comprise only $2 \%$ of the population. Great Andamanese were once the largest tribal community inhabiting the major islets of Andamans but are now restricted to Strait Island of the South Andaman (Sharief 2007). Great Andamanese, Onge, Jarawa, and Sentinelese are the critically endangered tribes. Shompens, Sentenalese, Onge, and Jarawa tribes are restricted to core forest areas (Sharief 2007). Onge and Shompens inhabit Little Andaman and Great Nicobar, respectively (Bhargava 1983, Elanchezhian et al. 2007). Jarawas reside both in middle and northern part of South Andamans which is demarcated as Jarawa reserve forest (Sharief 2007).

\section{The settlers of $A \& \&$ islands}

The $\mathrm{A} \& \mathrm{~N}$ islands were used as a penal colony by the British rulers to imprison rebels and freedom fighters, as well as hardened criminals. The settlers are largely comprised of descendents of ex-convicts who were held by the British in the Cellular Jail at Port Blair. These ex-convicts settled either in Port Blair or migrated to other islands of South Andaman. The ex-convicts were largely from the 
Mongoloid tribes and settlers of Andaman and Nicobar islands, India

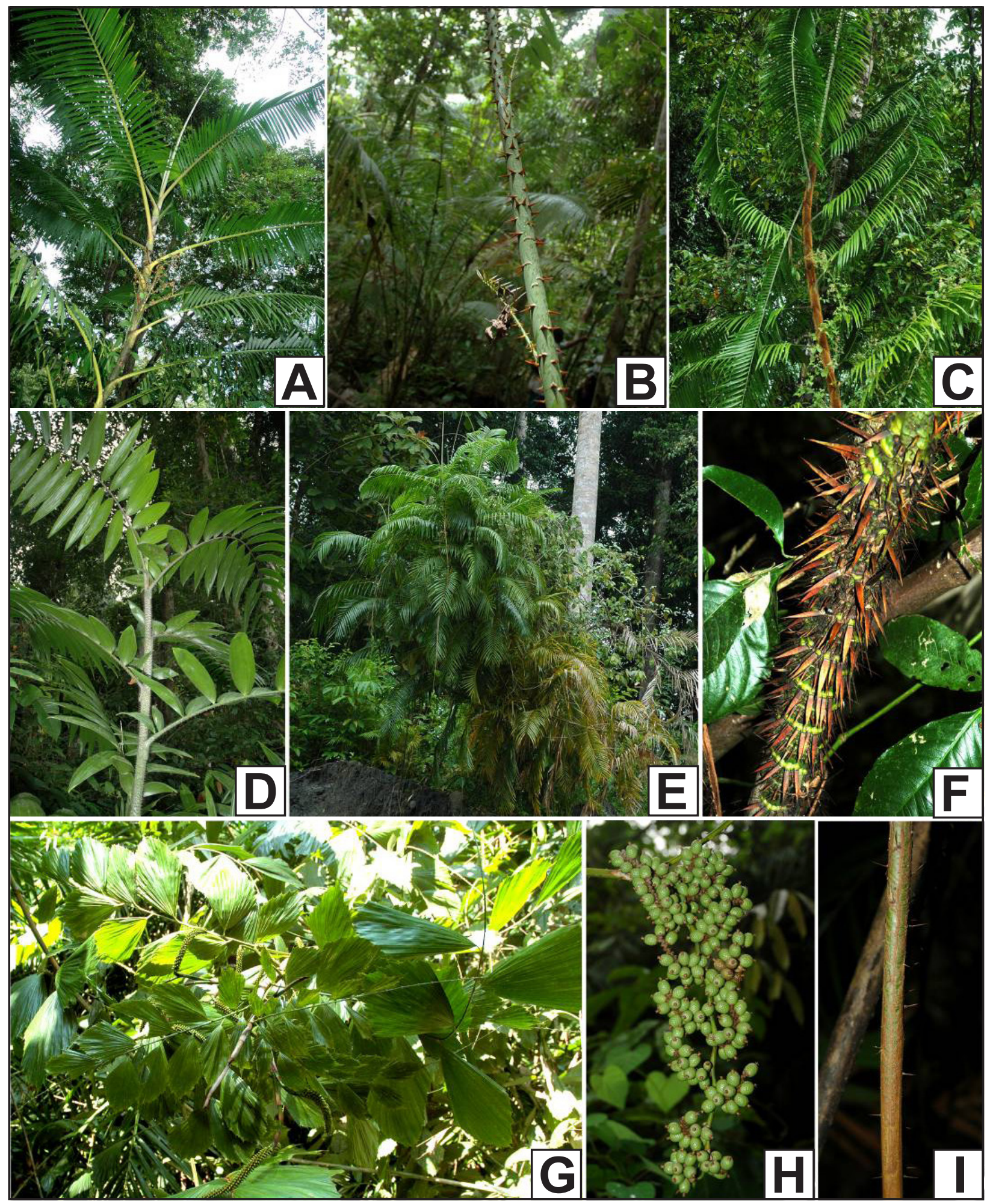

Figure 2. Rattans of Andaman and Nicobar islands, India. (A) Habit of Calamus andamanicus Kurz; (B) habit of Calamus baratangensis Renuka \& Vijayak.; (C) sheath armature of Calamus dilaceratus Becc.; (D) Calamus unifarius var. petong Becc.; (E) habit of clustering cane, Calamus pseudorivalis Becc.; (F) sheath of Calamus longisetus Griff.; (G) habit of Korthalsia laciniosa (Griff.) Mart.; (H) fruit of Calamus viminalis Willd.; (I) a thin stem of pencil cane, Korthalsia rogersii Becc. 
mainland and speak Bengali, Hindi, Urdu, Tamil, Telugu, and Malayalam.

Besides ex-convicts, the islands are populated by the migrant labor brought in to work in oil palm and timber plantations during the British rule and later on by the traders from independent India. People have also migrated from the coastal states of the mainland for work and economic establishment towards various kinds of trade and markets across Bay of Bengal. In fact, the biotic interference and socio-economic activities related to natural resources by settlers have not been studied earlier by any researcher in these islands.

\section{Results}

\section{Informants}

The age group of indigenous people interviewed ranged from 45 to 65 . There was no age limit for the interview with settlers and traders, but the average age of informants was 52. Multiple enquiries were conducted to get accurate information at each site. Due to restrictions by the ethnic communities, women were not interviewed.

\section{Distribution of rattans}

Rattans species, C. andamanicus, Calamus baratangensis Renuka \& Vijayak., Calamus basui Renuka \& Vijayak., Calamus dilaceratus Becc., Calamus longisetus Griff., C. palustris, Calamus pseudorivalis Becc., C. unifarius var. pentong, C. viminalis, Daemonorops kurziana Hook.f. ex Becc., Daemonorops manii Becc., K. laciniosa, and $K$. rogersii were recorded as integral livelihood material along with other palms among the ethnic tribals and settlers in the A \& N islands (Figure 2). Calamus ba- sui is found only in Little Andaman and can be easily distinguished from $C$. baratangensis by its vestigial cirrus. Korthalsia rogersii is endemic and scarcely distributed in the Andaman islands (Figure 2l). Daemonorops manii and D. kurziana are predominant in the islets of the South Andaman. Although $D$. manii is widespread throughout the Andamans, its allied species Daemonorops wrightmyoensis Renuka \& Vijayak., Daemonorops aurea Renuka \& Vijayak., and Daemonorops rarispinosa Renuka \& Vijayak. are restricted to the different reserve forests at Wrightmyo, Shoal bay, and Little Andaman, respectively. Daemonorops kurziana sharing habitat in South Andamans with its allied species can be distinguished by its scarious armature of the sheath. In Nicobar, $C$. dilaceratus, $C$. pseudorivalis, and $K$. laciniosa are found in the peripheral areas of forests and littorals of Car Nicobar, Kamorta, Katchal, Trinkat, Little Nicobar, Nancowary, and Great Nicobar (Table 1; Figures 2C,E,G). Calamus unifarius var. pentong is rare, sporadic, and sheltered, preferably in the canopies of tropical rain forests of Great Nicobar and core forests of Kamorta (Figure 2D).

\section{Ethnic usage of rattans in the $A \& N$ islands by the aboriginals and settlers}

Nicobarese use canes for making huts, bridges, platforms, baskets, furniture, twines, ropes, and handicrafts (Table 2). They also use sticks made of canes for ritual fights and arrows made of canes for hunting (Table 2). Likewise, Shompens are also largely dependent on rattans. They eat young shoots and fruit of $C$. dilaceratus, use its leaves with species of Pinanga and Nypa for thatching, and use peeled stem of $C$. pseudorivalis for twining to make huts (Figure 3B). They also collect water for drinking from the pith of $C$. dilaceratus (Table 2). Until a few decades ago, none of the six species of rattans reported from the

Table 2. Ethnic uses of rattans by Shompens and Nicobarese of the Nicobar islands, India.

\begin{tabular}{|c|c|c|c|c|}
\hline \multirow[t]{2}{*}{ Species } & \multirow{2}{*}{$\begin{array}{l}\text { Common } \\
\text { names }\end{array}$} & \multicolumn{3}{|l|}{ Uses of parts } \\
\hline & & Stem & Leaves & Fruit \\
\hline $\begin{array}{l}\text { Calamus } \\
\text { dilaceratus } \\
\text { Becc. }\end{array}$ & $\begin{array}{l}\text { pathi beth, } \\
\text { woolaiyo } \\
\text { (Shompen) }\end{array}$ & $\begin{array}{l}\text { Making furniture. } \\
\text { To make fighting sticks for rituals. } \\
\text { For thatching. } \\
\text { To make handles for various materials like knives. } \\
\text { Petiole/rachis used as a coconut scraper (Figure } \\
\text { 3G) by Nicobarese due to its roughness. }\end{array}$ & $\begin{array}{l}\text { Thatching } \\
\text { To make } \\
\text { fences } \\
\text { (Figure 2C) }\end{array}$ & $\begin{array}{l}\text { Edible; eaten } \\
\text { by Shompens } \\
\text { \& Nicobarese }\end{array}$ \\
\hline $\begin{array}{l}\text { Calamus } \\
\text { pseudorivalis } \\
\text { Becc. }\end{array}$ & $\begin{array}{l}\text { malay beth, } \\
\text { woolaiyo } \\
\text { (Shompen) }\end{array}$ & $\begin{array}{l}\text { Widely used as a rope for twining purposes. } \\
\text { A rafting material for making huts and also to make } \\
\text { circular tables. } \\
\text { High flexibility of this cane contributes to ornaments } \\
\text { such as hair band, bangles, etc. } \\
\text { Peeled cane used as hand grips for broomsticks, } \\
\text { knives, etc. (Figure 3E). }\end{array}$ & - & $\begin{array}{l}\text { Edible } \\
\text { occasionally }\end{array}$ \\
\hline $\begin{array}{l}\text { Calamus } \\
\text { unifarius var. } \\
\text { pentong Becc. }\end{array}$ & - & $\begin{array}{l}\text { Stem used along with mota beth for construction } \\
\text { of huts by Shompens (Figures 2D, 3A). }\end{array}$ & - & - \\
\hline
\end{tabular}


Senthilkumar et al. - Livelihood and Revenue: Role of rattans among

Mongoloid tribes and settlers of Andaman and Nicobar islands, India

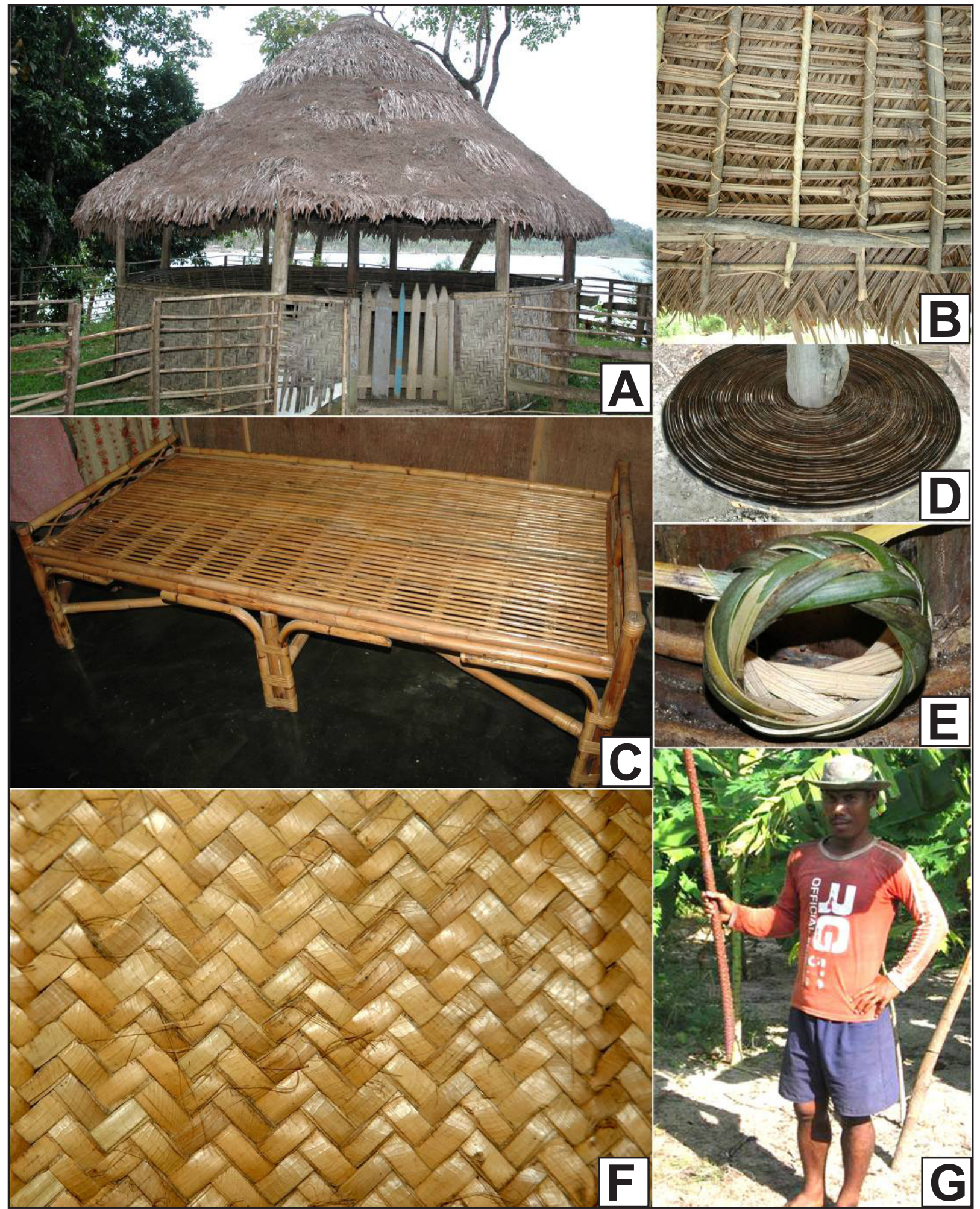

Figure 3. Utilization of rattans (canes) in Andaman and Nicobar islands, India. (A) Nicobarense hut at Great Nicobar; (B) canes used for thatching (Calamus dilaceratus Becc.) and twining (Calamus pseudorivalis Becc.); (C) sleeping cot made of canes alone; (D) circular table mat from mixture of Calamus unifarius var. pentong Becc. and C. pseudorivalis; (E) knife grip made from C. pseudorivalis; (F) sleeping mat from Calamus baratangensis Renuka \& Vijayak.; (G) a nicobari holding the leafless rachis of $C$. dilaceratus which is used as a coconut scraper in Nicobar Islands. 
Table 3. Uses of rattans by settlers of the Andaman islands, India.

\begin{tabular}{|c|c|c|c|c|}
\hline \multirow[t]{2}{*}{ Species } & \multirow{2}{*}{$\begin{array}{l}\text { Common } \\
\text { names }\end{array}$} & \multicolumn{3}{|l|}{ Uses of parts } \\
\hline & & Stem & Leaves & Fruit \\
\hline $\begin{array}{l}\text { Calamus andamanicus } \\
\text { Kurz }\end{array}$ & $\begin{array}{l}\text { mota } \\
\text { beth, } \\
\text { husli } \\
\text { songa } \\
\text { beth }\end{array}$ & $\begin{array}{l}\text { Making furniture (Figure } 2 \mathrm{~A}, 3 \mathrm{C} \text { ). } \\
\text { Preferred for hut making. } \\
\text { Making handles for various materials like knives. } \\
\text { Making platforms, bridges, and fences. }\end{array}$ & $\begin{array}{l}\text { Thatching } \\
\text { and making } \\
\text { fences }\end{array}$ & - \\
\hline $\begin{array}{l}\text { Calamus baratangensis } \\
\text { Renuka \& Vijayak. }\end{array}$ & $\begin{array}{l}\text { malay } \\
\text { beth }\end{array}$ & $\begin{array}{l}\text { Widely used as rope material. } \\
\text { Well known rafting material in making huts and } \\
\text { fences. (Figure 2B) } \\
\text { Basic material for making bangles and jewels and } \\
\text { also used as supplementary material along with } \\
\text { bamboos for ornaments. } \\
\text { Making handles for broomsticks, knives, etc. }\end{array}$ & - & Edible \\
\hline Calamus longisetus Griff. & $\begin{array}{l}\text { jungli } \\
\text { beth }\end{array}$ & $\begin{array}{l}\text { Furniture industries. (Figure } 2 \mathrm{~F} \text { ) } \\
\text { Widely used for making furniture and fences. }\end{array}$ & - & - \\
\hline $\begin{array}{l}\text { Calamus basui } \\
\text { Renuka \& Vijayak. }\end{array}$ & $\begin{array}{l}\text { safed } \\
\text { beth }\end{array}$ & $\begin{array}{l}\text { Same ethnic uses and trade utility as } C . \\
\text { baratangensis. }\end{array}$ & - & - \\
\hline Calamus palustris Griff. & $\begin{array}{l}\text { dunda } \\
\text { beth }\end{array}$ & $\begin{array}{l}\text { Used with other non-traded canes for fencing. } \\
\text { Used in construction of bridges for creeks. }\end{array}$ & - & - \\
\hline Calamus viminalis Willd. & $\begin{array}{l}\text { dudh } \\
\text { beth }\end{array}$ & $\begin{array}{l}\text { Easily breakable. Not exploited for commercial } \\
\text { purposes. }\end{array}$ & - & $\begin{array}{l}\text { Edible } \\
\text { (Figure } \\
2 \mathrm{H} \text { ) }\end{array}$ \\
\hline $\begin{array}{l}\text { Daemonorops manii } \\
\text { Becc., Daemonorops } \\
\text { kurziana Hook.f. ex Becc., } \\
\text { Daemonorops rarispinosus } \\
\text { Renuka \& Vijayak. }\end{array}$ & $\begin{array}{l}\text { songa } \\
\text { beth }\end{array}$ & $\begin{array}{l}\text { Same ethnic uses and trade utility as } C . \\
\text { andamanicus. }\end{array}$ & $\begin{array}{l}\text { For } \\
\text { thatching }\end{array}$ & - \\
\hline $\begin{array}{l}\text { Korthalsia laciniosa } \\
\text { (Griff.) Mart. }\end{array}$ & $\begin{array}{l}\text { rassi } \\
\text { beth, } \\
\text { rope } \\
\text { beth }\end{array}$ & $\begin{array}{l}\text { Small diameter canes used as fencing materials } \\
\text { (Figure } 2 G, 3 A \text { ). } \\
\text { Making house decorations such as tables and } \\
\text { benches (Figure 3D). }\end{array}$ & $\begin{array}{l}\text { Decorative } \\
\text { purposes }\end{array}$ & - \\
\hline Korthalsia rogersii Becc. & $\begin{array}{l}\text { pencil } \\
\text { beth }\end{array}$ & $\begin{array}{l}\text { Due to its high flexibility and peeling nature, this } \\
\text { has been extensively used in handicraft industries } \\
\text { (Figure } 6 \mathrm{C} \text { ). }\end{array}$ & $\begin{array}{l}\text { Decorative } \\
\text { purposes }\end{array}$ & - \\
\hline
\end{tabular}

Nicobar islands were found in trade (Table 2). Calamus unifarius var. pentong and $K$. laciniosa are used as rafting material due to their flexibility (Table 2). In addition, the rhomboid shaped leaves of $K$. laciniosa are used for house decorations along with coconut leaves during rituals and ceremonies by Nicobarese (Table 2; Figure 2G). Indigenous tribal and mainland community knowledge of canes has been partially adopted by the settlers, too (Table 3). Calamus andamanicus, C. baratangensis, C. longisetus, Daemonorops spp., and Korthalsia spp. are mainly used for making chairs, sleeping mats, baskets, and fences (Figures 3A,C,F). Fruit of C. viminalis are edible (Figure 2H).

\section{Role of settlers in rattan trade}

Calamus andamanicus, C. baratangensis, C. longisetus, Daemonorops spp., and Korthalsia spp. are widespread and widely traded because of their various uses in the cane industry (Table 3). The processing of canes from collection to bundling is done on Bakultala island, South Andaman, before being exported to the mainland and to other Asian markets (Figure 4). Extraction of cane is performed by the cane collectors on contract basis from the forest department (Figure 4). Canes are harvested from the rattan-rich areas such as Shoal bay, Mannarghat, Wumberleygunj, and Ferrargunj of South Andaman, and Mayabunder, Rangat, and Kadamthala of middle Andaman by the forest department. The harvested canes are processed in Ferrargunj, Mathura, Billiground, and Nimbudera (Figure 5). For the flexible canes, not much processing is required except bundling (Figure 6D), but for the inflexible canes, multiple processing is done. The process involves the following sequential steps to get the final product: boiling \& straightening of the material, drying, and bundling (Figures $7 A, B, C$ ). Stems that measure up to 


\section{Senthilkumar et al. - Livelihood and Revenue: Role of rattans among Mongoloid tribes and settlers of Andaman and Nicobar islands, India}

Table 4. Export rate and trade norms of rattans from the Andaman and Nicobar islands, India. *Daemonorops species are mixed together in a same trade name songa beth. Grades (A, B, C) refer to the trade grading of the canes. Textures: Channelled (C), Powdery smooth (P), Rough (R), Smooth (M), Soft (O). Flexibility: Flexible (F), Highly flexible $(\mathrm{H})$, Inflexible (I). Stem size $=$ length $X$ breadth in $\mathrm{cm}$.

\begin{tabular}{|c|c|c|c|c|c|c|c|c|}
\hline \multirow[t]{2}{*}{ Species } & \multirow{2}{*}{$\begin{array}{l}\text { Trade } \\
\text { names }\end{array}$} & \multirow[b]{2}{*}{$\begin{array}{l}\frac{0}{0} \\
\frac{\pi}{0} \\
0\end{array}$} & \multirow[b]{2}{*}{ 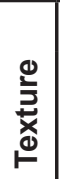 } & \multirow[b]{2}{*}{ 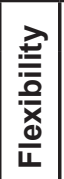 } & \multirow{2}{*}{$\begin{array}{l}\text { Stem size } \\
\text { based on } \\
\text { trade norms } \\
(\mathrm{cm})\end{array}$} & \multicolumn{2}{|c|}{ Cane rate (rupees) } & \multirow{2}{*}{$\begin{array}{l}\text { Export } \\
\text { per year } \\
\text { (tonnes) }\end{array}$} \\
\hline & & & & & & Collector & Exporter & \\
\hline Calamus andamanicus Kurz & mota beth & $A$ & $M$ & I & $90 \times 5$ & $25-30$ & 200 & 200 \\
\hline $\begin{array}{l}\text { Calamus baratangensis Renuka \& } \\
\text { Vijayak. }\end{array}$ & malay beth & $A$ & $\mathrm{M}$ & $\mathrm{H}$ & $\sim 300 \times 1.5$ & 50 & 150 & 100 \\
\hline Calamus basui Renuka \& Vijayak. & safed beth & $\mathrm{A}$ & $\mathrm{P}$ & $\mathrm{H}$ & $\sim 300 \times 1$ & 50 & 150 & 50 \\
\hline Calamus longisetus Griff. & jungli beth & $\mathrm{C}$ & $\mathrm{C}$ & 1 & $100 \times 2.5-3$ & $10-20$ & 150 & 30 \\
\hline Daemonorops manii Becc. & songa beth & $\mathrm{B}$ & $M$ & $\mathrm{I}$ & $90 \times 5$ & $25-30$ & 200 & 100 \\
\hline Korthalsia laciniosa (Griff.) Mart. & rasi beth & $\mathrm{B}$ & $\mathrm{R}$ & $\mathrm{F}$ & $\sim 300 \times 1.5-2$ & 100 & 250 & 10 \\
\hline Korthalsia rogersii Becc. & pencil beth & $A$ & $\mathrm{O}$ & $F$ & $\begin{array}{l}\sim 300 \times \\
0.5-0.8\end{array}$ & 80 & 200 & 5 \\
\hline
\end{tabular}
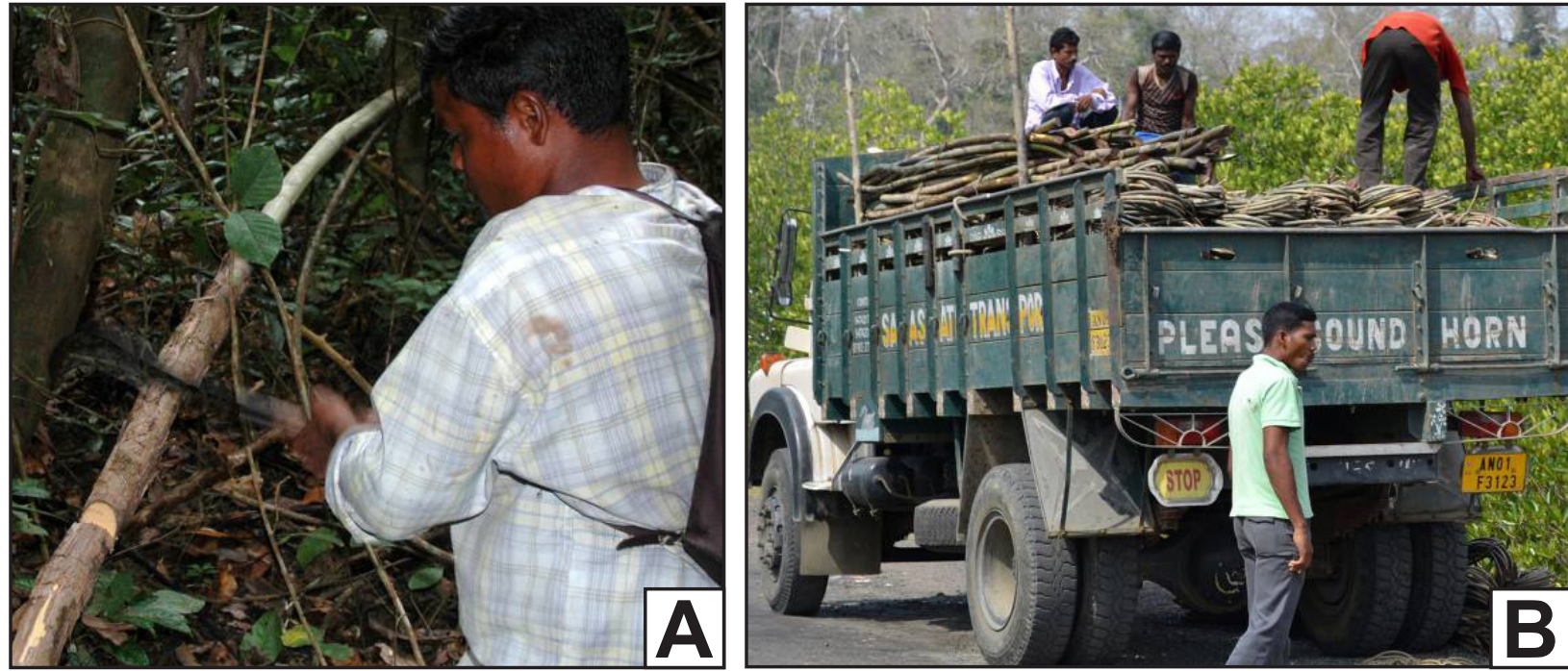

Figure 4. Collection and transportation of canes in Andaman and Nicobar islands, India. (A) A person collecting cane from the wild; (B) canes are transported via road to the processing units after they are transferred from the boats; (C) canes are transported over creeks via boats at Baratang island, South Andaman.

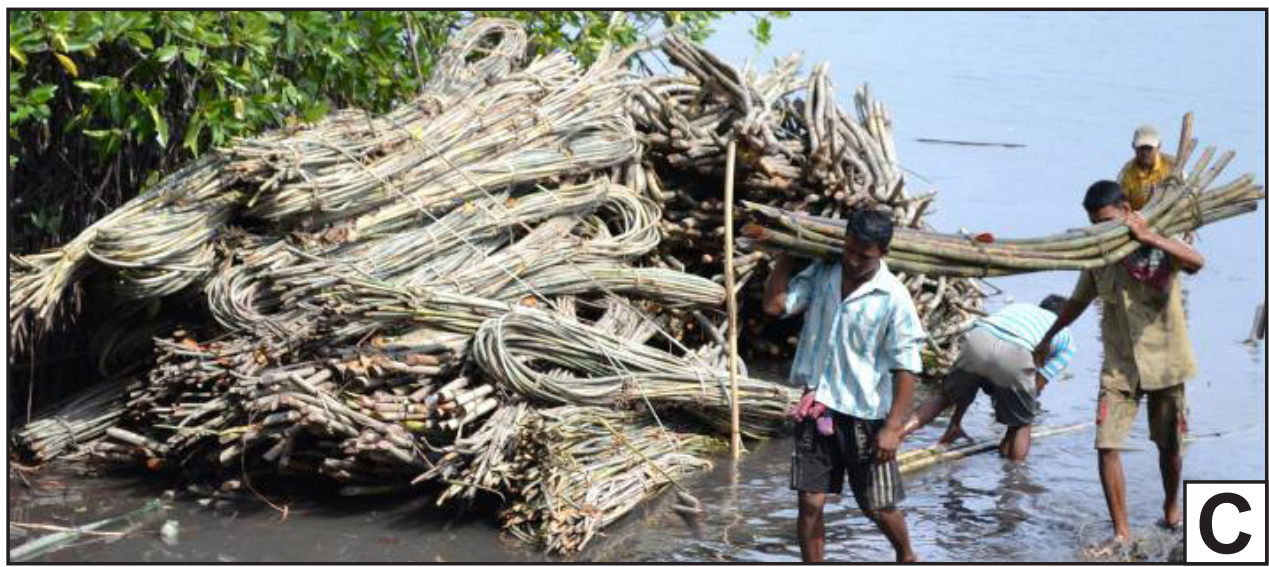




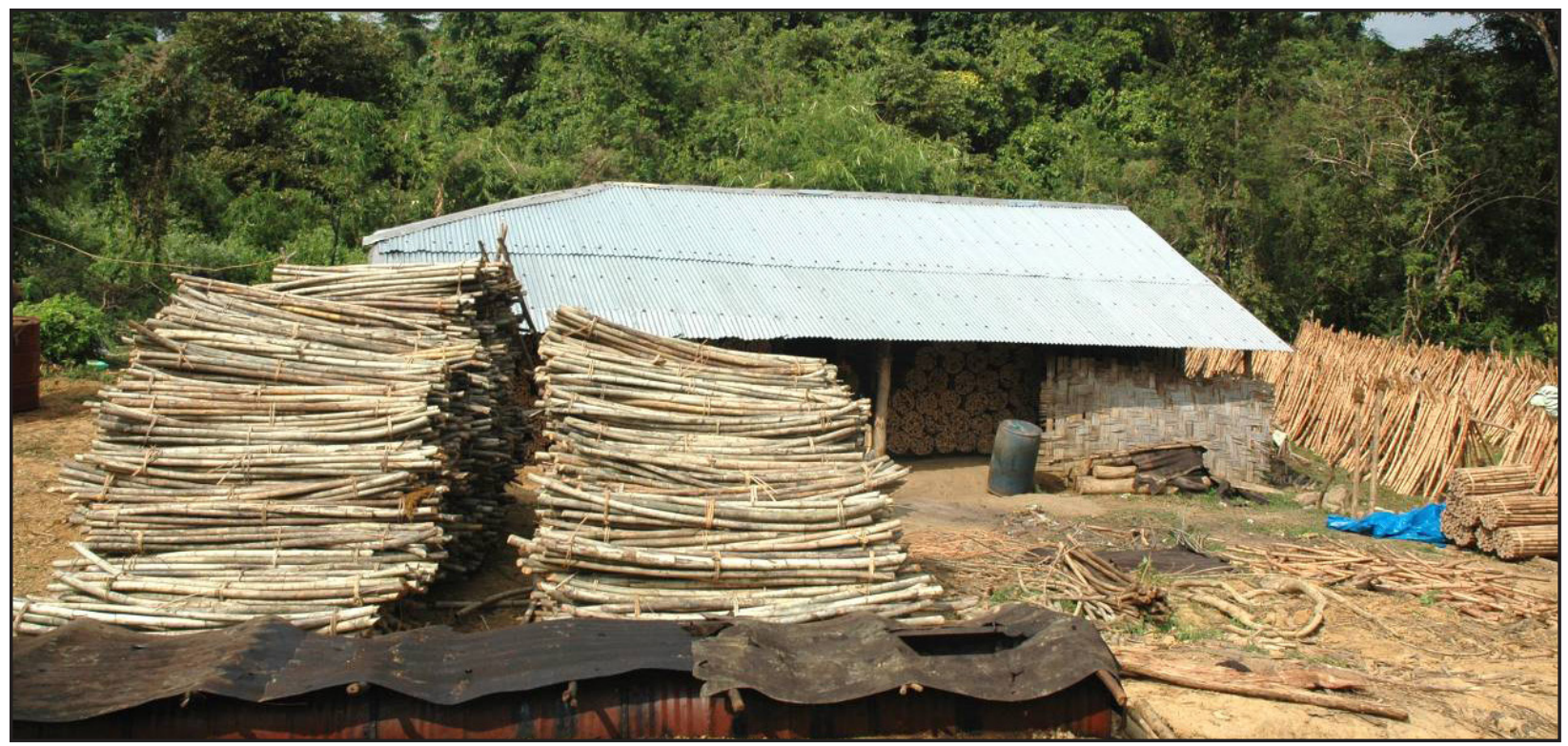

Figure 5. Cane processing unit at Ferrargunj, South Andaman, which pools the canes from Shoal bay, Mannarghat, and other places of South Andaman, India.

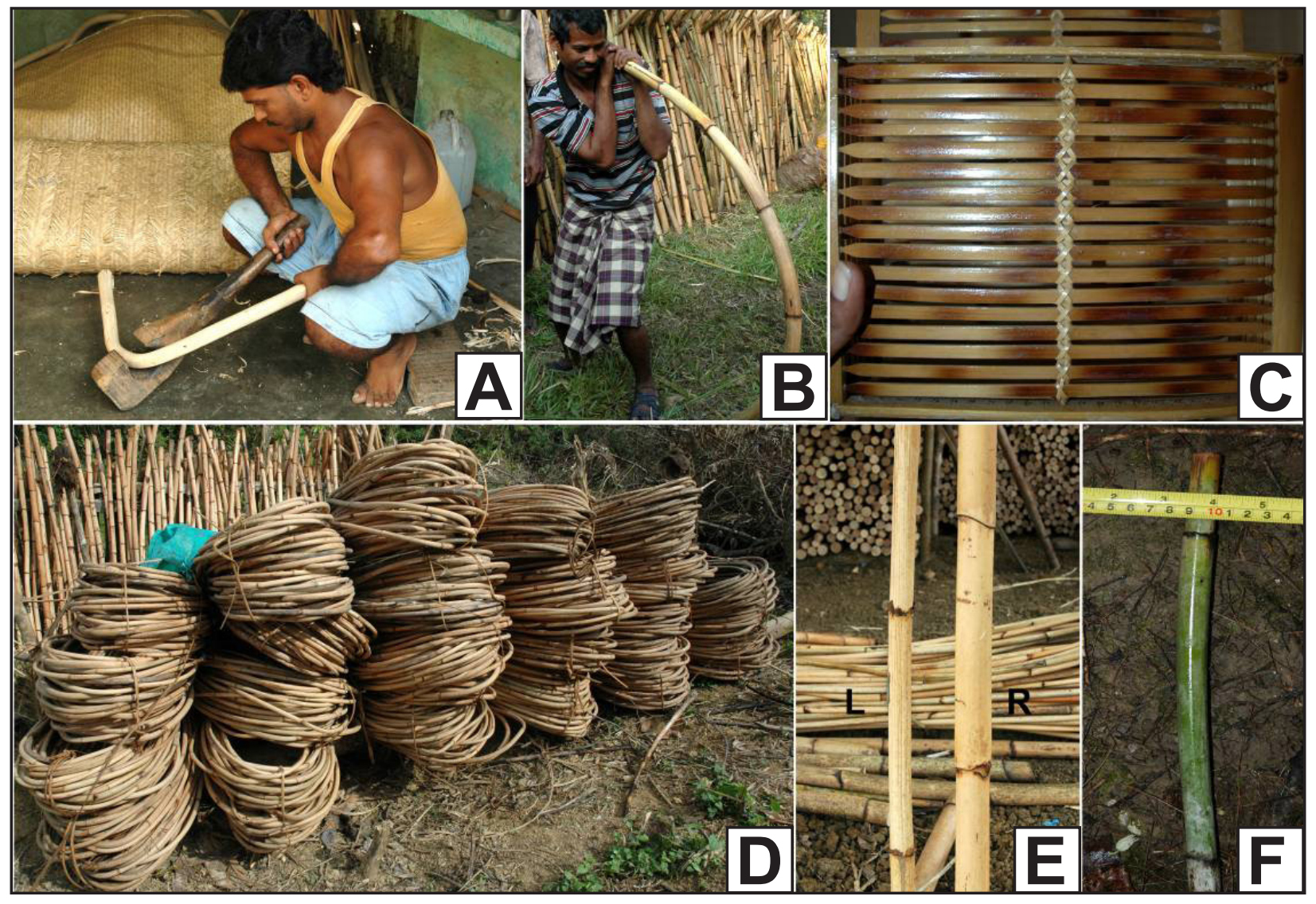

Figure 6. Utilization of rattans (canes) in Andaman and Nicobar islands, India. (A) Making furniture; (B) checking flexibility of canes; (C) Korthalsia rogersii Becc. in handicrafts; (D) bundled flexible canes; (E) canes with grades A-C (Left: Calamus longisetus Griff., Grade-C; Right: Calamus andamanicus Kurz, Grade-A); (F) Calamus baratangensis Renuka \& Vijayak. (Grade-A). 


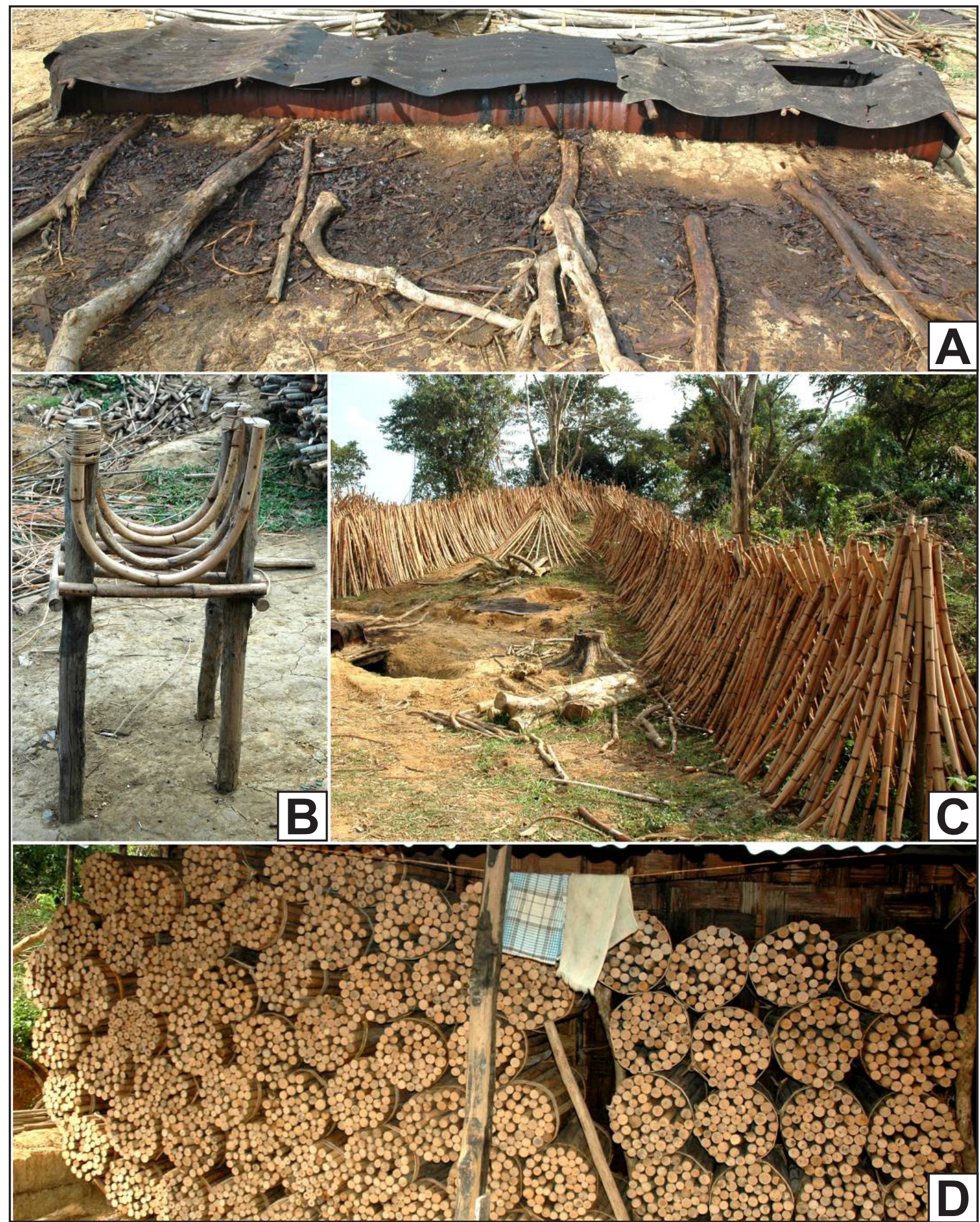

Figure 7. Steps involved in processing of canes in Andaman and Nicobar islands, India. (A) Boiling of cane culms in diesel; (B) cane straightening using u-shaped bending setup at the processing unit; (C) the straightened canes are dried under sunlight; (D) canes are bundled based on the trade norms for the market export. 
$90 \mathrm{~cm}$ long (as prescribed in trade code) are bundled in 50 s according to the industrial norms (Figure 7D). However, C. baratangensis, C. basui, $K$. laciniosa, and K. rogersii are bundled and marketed directly without any processing (Figure 6D). Canes are graded as either A, B, or $\mathrm{C}$ based on the quality and texture. Korthalsia laciniosa and $C$. longisetus are grouped as $\mathrm{C}$-grade canes, which are utilized by the locals to make fences, huts, and agriculture implements (Figure 6A). Korthalsia rogersii is a small-sized, thin cane (called "pencil cane") and is in high demand as a major twining material for handicraft industries (Figures 2I, 6C). Daemonorops manii (B-grade cane) is transported to the mainland along with A-grade canes (Table 4). Calamus andamanicus is largely exported to mainland as well as to the European markets along with other mainland canes. The trade name songa beth is applied to a mixture of $C$. andamanicus and Daemonorops species ( $D$. manii and $D$. kurziana). The bulk of the rattan trade $(41 \%)$ is of mota beth (C. andamanicus) alone (Figure 6E). Calamus baratangensis, $K$. laciniosa, and $K$. rogersii have high market demand, but they are exported in minimum quantity when compared to $C$. andamanicus.
Calamus basui and C. baratangensis are known by the same trade name malay beth (Figure 6F).

\section{Rattan export and revenue flow}

Sixty-one percent of the total rattan trade in the islands is represented by $C$. andamanicus (mota beth) and Daemonorops spp. (songa beth) (Figures 6B, 8). Korthalsia laciniosa and $K$. rogersii are exported less (collectively $3 \%$ ) but are the highly valued species in trade, equal to mota beth (Figure 8). Calamus longisetus is not exported but is locally utilized, it being a cheaper source (Figure 8). Calamus basui is exported largely from Little Andaman as malay beth but is often mixed with $C$. baratangensis because of their co-occurrence.

The revenue of the exports varies among traders because of the seasonal tenders, scarcity of resources, and industrial demands. For example, the rate of $K$. rogersii (pencil cane) was found to be relatively high due to demand as well as rarity in the market. There are three kinds of stakeholders in the trade (Figure 8): (A) collectors who are not

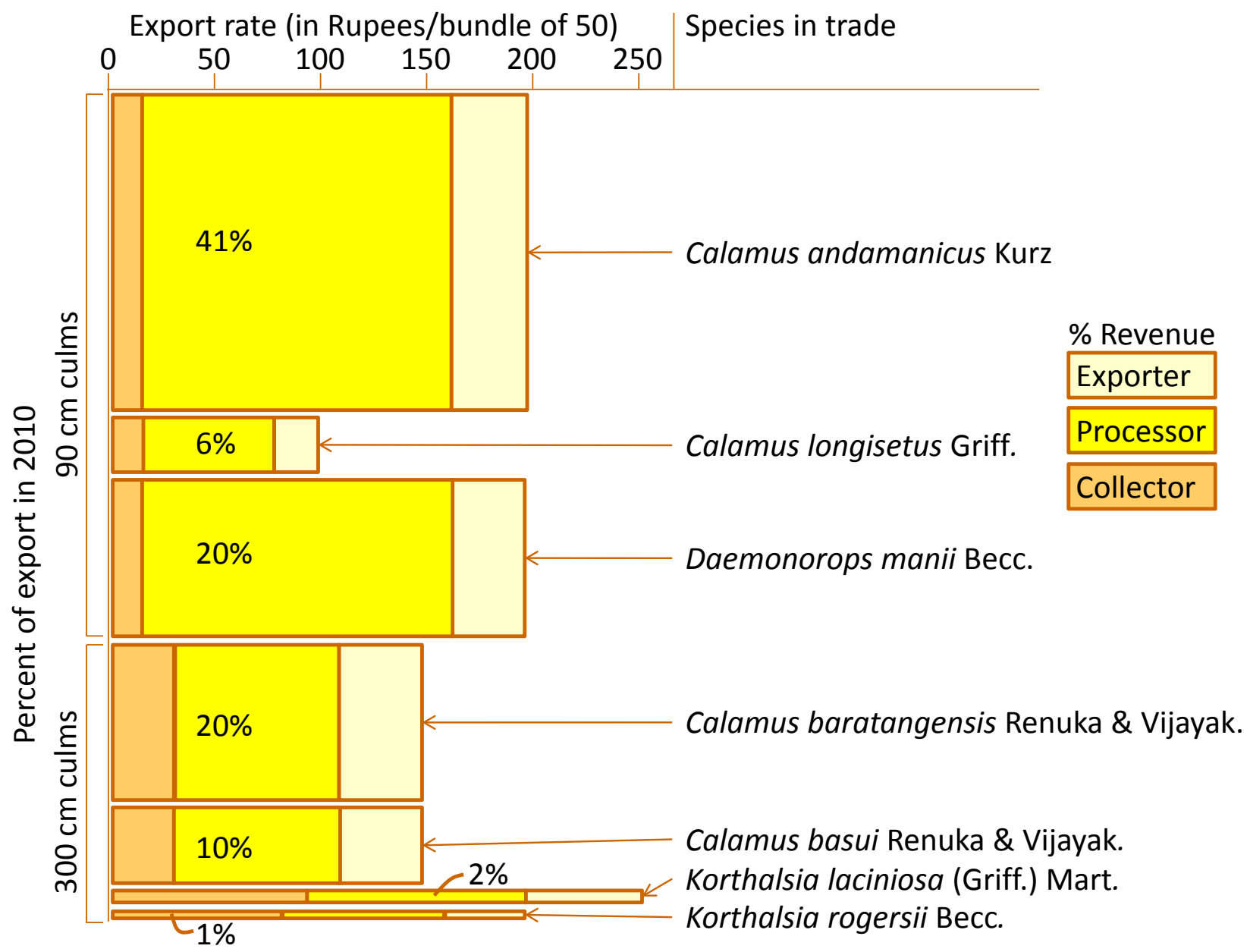

Figure 8. Rattan cane export market in 2010 from the Andaman and Nicobar islands, India. Export rate (in Rupees/ bundle of 50 canes), percent of exports by species, and percent of revenue earned by collectors, procesors, and exporters, for flexible and inflexible rattan cane species. 


\section{Senthilkumar et al. - Livelihood and Revenue: Role of rattans among Mongoloid tribes and settlers of Andaman and Nicobar islands, India}

involved in the cane processing and export (Figure 4A); (B) processors, some of whom both collect and process and some who process alone (Figures 4B,C); and (C) exporters who only export and are not involved in processing. The revenue is compared based on the market rate of each type of cane, and the benefit share is calculated at each level of trade, i.e., collectors, processors, and exporters (Figure 8). The revenue or cane rate for each species varies between collectors and exporters (Table 4). Collectors prefer to harvest flexible canes (which do not require processing) because the revenue earned is higher than for the other canes (Figure 8).

\section{Discussion}

Rattans in Great Nicobar and other Nicobar group of islands meet the livelihood requirements of Shompens and Nicobarese, respectively (Dagar \& Dagar 1991, Sharief \& Rao 2007). Processors earn more income for the abundant, highly traded and inflexible canes (which require processing) because they collect and process in bulk. Exporters play a major role as intermediaries to facilitate the trade and earn reasonable income.

Rattans have become an integral part of the life of many ethnic communities in South and Southeast Asia. The knowledge of utilization is variable across the regions and by the different communities. In Andaman and Nicobar islands, rattan utilization by the ethnic communities is thought to be sustainable. However, unsustainable and unscientific extraction of canes by traders could lead to population declines and to extermination of populations of both common and rare species especially in the Bay islands. With increase in the demand for rattan resources and projected demand in the coming years, the demand will soon outrun the stock. Besides the extraction pressures, rattans are also severely threatened by changes in land use patterns such as conversion of forest lands to agriculture and plantations and by other anthropogenic sources. The threat is also accentuated since most of the rattans are dioecious and take about 10-12 years before they flower and set fruit. Thus, premature harvest could also adversely affect regeneration of most of the rattan species.

\section{Conclusion}

Considering the economic and cultural importance of the species to local livelihoods, it is expected that the pressure on rattans is only going to increase. In this context, an overarching plan to conserve rattan resources will need to incorporate strong data on their distribution and their threats as well as establish the impact that indiscriminate harvesting could have on the population genetic parameters. Developing silviculture practices to harvest rattans on a rotational basis could also help avert their loss while meeting trade demand. Secondly, trade of rattans needs to be regularized and benefits shared appropriately across the trade spectrum from collectors to consumers without any intermediaries.

\section{Acknowledgments}

We are thankful to the Principal Chief Conservator of Forests, Haddo, Port Blair, and Chief Wildlife warden, Haddo, Port Blair, for permission to explore the forests throughout the $A$ \& $N$ islands and also thankful to the forest officials and forest guards, who helped as interpreters. We are grateful to the Deputy Commissioner, Port Blair, for providing access to Nicobar and Little Andaman. We thank Dr. C. Murugan, Scientist "C," Ms. Lakra, Botanist of the Andaman \& Nicobar regional center, BSI, for their helpful guidance to visit different localities. We thank Mr. Nehru, SACON, for his timely help in the field. We are grateful to Dr. Shyamal K. Basu, Agri-Horticultural Society of India, Kolkata, and Dr. Haridasan, I-AIM, Bangalore, for the species authentication. We also acknowledge the Department of Biotechnology, Government of India, for its financial support to carry out this study. We would like to thank the reviewers for useful suggestions which have vastly improved the manuscript.

\section{Literature Cited}

Alfred, J. R.B., A.K. Das \& A.K. Sanyal. 2002. Ecosystems of India. ENVIS-Zoological Survey of India, Kolkata, India.

Alfred, J.R.B. \& S. Chakraborty. 2002. Endemic Mammals of India. Zoological Survey of India, Kolkata, India.

Anonymous. 2011. Census 2011 for Andaman and Nicobar Islands. Census Directorate, Andaman and Nicobar Islands, India.

Awasthi, A.K. 1991. Ethnobotanical studies of the Negrito islanders of Andaman Islands, India: The Great Andamanese. Economic Botany 45(2):274-280.

Balakrishnan, N.P. 1989. Andaman Islands-vegetation and floristics. Pp. 56-88 in Andaman, Nicobar and Lakshadweep: An impact assessment. Edited by C.J. Saldanha. Oxford \& IBH Publishing Co. Pvt. Ltd., New Delhi, India.

Balakrishnan, N.P. \& J.L. Ellis. 1996. Andaman and Nicobar Islands. Pp. 523-538 in Flora of India. Part 1. Edited by P.K. Hajra, B.D. Sharma, M. Sanjappa, and A.R.K. Sastry. Botanical Survey of India, Calcutta, India.

Basu, S.K. 1992. Rattans (Canes) in India: A monographic revision. Rattan Information Centre, Kepong, Kuala Lumpur. 
Bhargava, N. 1983. Ethnobotanical studies of the tribes of Andaman and Nicobar Islands, India. I. Onge. Economic Botany 37(1):110-119.

Champion, H.G. \& S.K. Seth. 1968. A Revised Survey of the Forest Types of India. Government of India Publication Division, New Delhi, India.

Chauhan N., H. Padalia, S. Gupta, M.C Porwal \& P.S. Roy. 2004. Nicobari tribe of the Car Nicobar Island: Keeping in pace with time. Journal of Human Ecology 16(3):155-161.

Cl. 2013. Biodiversity Hotspots. Conservation International. www.biodiversityhotspots.org

Dagar, H.S. \& J.C. Dagar. 1991. Plant folk medicines among the Nicobarese of Katchal Island, India. Economic Botany 45(1):114-119.

Dransfield, J., N.W. Uhl, C.B. Asmussen, W.J. Baker, M.M. Harley \& C.E. Lewis. 2008. Genera Palmarum. The evolution and classification of palms. Kew Publishing, Royal Botanic Gardens, Kew, Richmond, Surrey, U.K.

Elanchezhian, R., R. Senthil Kumar, S.J. Beena \& M.A. Suryanarayana. 2007. Ethnobotany of Shompens - A primitive tribe of Great Nicobar Island. Indian Journal of Traditional Knowledge 6(2):342-345.

Henderson, A. \& F. Henderson. 2007. New species of Calamus from Laos and Myanmar. Taiwania 52(2):152-158.

ISE (International Society of Ethnobiology). 2006. International Society of Ethnobiology Code of Ethics. http://ethnobiology.net/code-of-ethics/.

Mapmaker v1.0. 2010. MapMaker Software. Natural Earth Community. http://kiwi.cs.dal.ca/GenGIS/MapMaker

Padalia, H., N. Chauhan, M.C. Porwal \& P.S. Roy. 2004. Phytosociological observations on tree species diversity of Andaman Islands, India. Current Science 87(6):799806.

Peters, C.M., A. Henderson, U.M. Maung, U.S. Lwin, U.T.M. Ohn, U.K. Lwin \& U.T. Shaung. 2007. The rattan trade of northern Myanmar: Species, supplies, and sustainability. Economic Botany 61(1):3-13.
Ravikanth, G., K.N. Ganeshaiah \& R. Uma Shaanker. 2001. Mapping genetic diversity of rattans in Central Western Ghats: Identification of hot-spots of variability for in situ conservation. Pp. 69-83 in Forest Genetic Resources: Status, threats and conservation strategies. Edited by R. Uma Shaanker, K.N. Ganeshaiah, and K.S. Bawa. Oxford and IBH Publishing Co. Pvt. Ltd., New Delhi, India.

Ravikanth, G., K.N. Ganeshaiah \& R. Uma Shaanker. 2002. Identification of hot spots of species richness and genetic variability in rattans: An approach using geographical information systems (GIS) and molecular tools. Plant Genetic Resources Newsletter (Rome, Italy: 1979) 132:17-21.

Renuka, C., K.V. Bhat \& R.C. Pandalai. 2010. Rattans of India: Taxonomy, biology and utilization. Kerala Forest Research Institute, Peechi, India.

Saldanha, C.J. 1987. The Andaman and Nicobar Islands: An environmental impact assessment. Ministry of Environment, Forests and Wild Life, Government of India, New Delhi, India.

Sharief, M.U. 2007. Plants folk medicine of Negrito tribes of Bay Islands. Indian Journal of Traditional Knowledge 6(3):468-476.

Sharief, M.U. \& R.R. Rao. 2007. Ethnobotanical studies of Shompens-A critically endangered and degenerating ethnic community in Great Nicobar Island. Current Science 93(11):1623-1628.

Singh, B.H., L. Puni, A. Jain, R.S. Singh \& P.G. Rao. 2004. Status, utility, threats and conservation options for rattan resources in Manipur. Current Science 87(1):90-94.

The Plant List. 2014. The Plant List. Version 1.1. www.theplantlist.org. Accessed 22 Jan 2014.

Tropicos.org. 2014. Tropicos, Botanical Information System. Missouri Botanical Garden. www.tropicos.org. Accessed 22 Jan 2014.

Uma Shaanker, R., K.N. Ganeshaiah, K. Srinivasan, V.R. Rao \& L.T. Hong. 2004. Bamboos and Rattans of the Western Ghats: Population biology, socio economics and conservation strategies. Ashoka Trust for Research in Ecology and the Environment (ATREE), Bangalore, India. 